\title{
Model Pengembangan Klinik Berhenti Merokok di Wilayah Tengerang Selatan Menggunakan Pendekatan Soft System Methodology
}

\author{
Izza Hananingtyas ${ }^{1^{*}}$ \\ ${ }^{1}$ Fakultas IImu Kesehatan; UIN Syarif Hidayatullah Jakarta; Jl. Kertamukti No.5, Pisanagn, \\ Ciputat. Telp. (021)74725718; e-mail: izza.hananingtyas@uinjkt.ac.id \\ *Korespondensi: e-mail: izza.hananingtyas@uinjkt.ac.id
}

Submitted: 02/01/2021; Revised: 09/01/2021; Accepted: 16/01/2021; Published: 29/01/2021

\begin{abstract}
Smoking behaviour has become a habit and culture in Indonesian society. According to WHO (2018), Indonesia is the second country with the largest number of smokers among people aged $\geq 15$ in the world after France in 2016. The Indonesian Ministry of Health in 2018 stated that the prevalence of smoking was $31.3 \%$ in Banten Province, this exceeds the National average of 29.3\%. An aim of our analysis was to prevent and reduce smoking behaviour. Public Health Experts has a moral responsibility to overcome problems of smoking behaviour in South Tangerang by "Smoking Cessation Clinic". They did this analysis by Soft System Methodology (SSM). It can be used to resolved high complexity problem for change habits and culture in society through strategic thinking and solutions. Result analysis of SSM showed that development model Smoking Cessation Clinic program can be held through electronic education activities by the android application. It designed as a media of alternative development to provide online education to the public. It is hoped that there will be routine educational activities that can be carried out by health cadres, so that the Smoking Cessation Clinic program can be socialized and can be utilized optimally to the community.
\end{abstract}

Keywords: Smoking Behaviour, Smoking Cessation Clinic, Soft System Methodology

\begin{abstract}
Abstrak
Perilaku merokok sudah menjadi kebiasaan dan budaya masyarakat Indonesia. Menurut WHO (2018), Indonesia merupakan negara kedua dengan jumlah perokok terbesar pada penduduk usia $\geq 15$ tahun di dunia setelah Perancis pada tahun 2016. Kementerian Kesehatan RI tahun 2018 menyatakan bahwa prevalensi merokok di Provinsi Banten sebesar 31,3\%, melebihi ratarata nasional sebesar $29,3 \%$. Tujuan dari analisis kami adalah untuk mencegah dan mengurangi perilaku merokok. Dokter Spesialis Kesehatan Masyarakat memiliki tanggung jawab moral untuk mengatasi masalah perilaku merokok di Tangerang Selatan melalui "Klinik Berhenti Merokok". Mereka melakukan analisis ini dengan Soft System Methodology (SSM). Ini dapat digunakan untuk memecahkan masalah kompleksitas tinggi untuk mengubah kebiasaan dan budaya dalam masyarakat melalui pemikiran dan solusi strategis. Hasil analisis SSM menunjukkan bahwa model pengembangan program klinik berhenti merokok dapat diimplementasikan melalui kegiatan edukasi elektronik dengan aplikasi android. Ini dirancang sebagai media pengembangan alternatif untuk memberikan pendidikan online kepada publik. Diharapkan ada kegiatan edukasi rutin yang dapat dilakukan oleh kader kesehatan, agar program Klinik Berhenti Merokok dapat tersosialisasi dan dapat dimanfaatkan secara maksimal kepada masyarakat.
\end{abstract}

Kata kunci: Perilaku Merokok, Klinik Berhenti Merokok, Metodologi Soft System 


\section{Pendahuluan}

Perilaku merokok merupakan kegiatan mengkonsumsi salah satu produk tembakau dengan cara membakarnya dan menghisap zat dari tanaman nicotina tabacum, nicotina rustica dan spesies lainnya atau sintetisnya dimana terkandung zat nikotin dan tar di dalam asapnya (Alamsyah, 2017). Indonesia merupakan negara kedua dengan jumlah perokok terbesar kalangan orang berusia $\geq 15$ di dunia setelah Perancis pada tahun 2016 (Geneva: World heald Organization, 2018). Konsumsi rokok yang meningkat berpengaruh pada tingginya beban penyakit akibat rokok dan bertambahnya jumlah kematian akibat rokok. WHO memperkirakan pada tahun 2030 angka kematian perokok di dunia akan mencapai 10 juta jiwa dan $70 \%$ diantaranya berasal dari negara berkembang. Saat ini, jumlah kematian akibat rokok mencapai $50 \%$ di negara berkembang. Setiap tahun, sekitar 225.700 orang di Indonesia meninggal akibat merokok atau penyakit lain yang berkaitan dengan tembakau.

Berdasarkan data dan informasi yang dirilis Kementerian Kesehatan pada tahun 2013 dan 2018 diketahui bahwa penggunaan tembakau di Indonesia masih tergolong tinggi di kalangan dewasa dan remaja. Prevalensi pada orang dewasa dari tahun 2013 sampai dengan tahun 2018 belum menunjukkan penurunan, sementara prevalensi merokok pada remaja usia 10-19 tahun mengalami peningkatan sebesar 20\%, yaitu dari 7,2\% di tahun 2013 menjadi 9,1\% pada 2018. Hal ini dipertegas dengan hasil laporan oleh Pusat Data dan Informasi Kementerian Kesehatan Indonesia tahun 2018, diketahui prevalensi perilaku merokok di Provinsi Banten melebihi angka rata-rata Nasional (29,3\%), yaitu sebesar 31,3\% (Kementrian Kesehatan RI, 2018).

Perilaku merokok ini dapat berpengaruh kepada masayarakat dari segi sosial, ekonomi, lingkungan dan kesehatan. Angka perilaku merokok indentik dengan penurunan sosial perekonomian, akibat dari pembelian rokok untuk kebutuhan sehari-hari. Begitu pula pada segi lingkungan dan Kesehatan, dimana diketahui bahwa zat aditif yang terkandung di rokok dapat menjadi polusi utama dalam rumah, yang secara segi Kesehatan dapat meningkatkan risiko penyakit tidak menular kronis seperti jantung, penyakit saluran pernafasan kronis, diabetes, dan kanker (WHO, 2020). Pemerintah telah melakukan berbagai pencegahan rokok yang telah diupayakan oleh Kemenkes yaitu dengan melakukan beberapa kegiatan yang di antaranya, memperingati Hari Tanpa Tembakau Sedunia (HTTS). Selain itu, Kemenkes juga melakukan kerjasama dengan Pemerintah Pusat dan Daerah serta seluruh masyarakat dalam mewujudkan Indonesia bebas asap rokok. Meski pemerintah telah gencar dengan berbagai cara untuk menciptakan kesadaran masyarakat, agar meninggalkan kebiasaan merokok, namun hasilnya belum terlihat secara signifikan.

Program Studi Kesehatan Masyarakat UIN Syarif Hidayatullah Jakarta, sebagai intitusi akademis yang terletak di wilayah Tangerang Selatan, memiliki tanggung jawab moral untuk mengatasi masalah hal pencegahan dan penurnan angka perilaku merokok di wilayah Tangerang Selatan. Dalam kegiatan pengabdian masyarakatnya Program Studi Kesehatan Masyarakat UIN Syarif Hidayatullah Jakarta bekerjasama dengan Pihak Dinas Kesehatan 
Tangerang Selatan, untuk membentuk Klinik Berhenti Merokok di Wilayah Puskesmas Kampung Sawah sebagai bentuk implementasi dari upaya pencegahan dan penurunan angka perilaku merokok. Pembentukan klinik berhenti merokok, dapat mencegah adanya gangguan mental pada pasien yang ingin berhenti merokok melalui pendampingan konseling (Davis et al., 2019).

Klinik Berhenti Merokok merupakan sarana yang menyediakan jasa konseling berhenti merokok, serta memberikan edukasi mengenai bahaya merokok. Implementasi pengendalian tembakau melalui klinik berhenti merokok, erat kaitannya dengan Teory of Planned Behaviour. Dalam merubah perilaku merokok di masyarakat untuk menjadi sebuah kebiasaan berdasarkan Teory of Planned Behaviour membutuhkan waktu 6 bulan, hal ini karena kompleksitas masalah yang dihadapi. dimana masalah penurunan angka merokok di masyarakat cenderung kompleks (Tseng et al., 2018). Untuk menghadapi masalah kompleksitas tersebut, maka digunakan Soft System Methodologi (SSM). Melalalui Soft System Methodologi (SSM) dapat diketahui mengenai analisa situasi / permasalahan pencegahan perilaku merokok sehingga dirancang alternatif pengembangan media untuk memberikan edukasi (Perdana et al., 2019). Maka dari itu dibutuhkan sebuah manajemen system untuk mendukung program Klinik Berhenti Merokok dalam penyebaran informasi dan edukasi tentang bahaya dan pencegahan perilaku merokok di wilayah Tangerang Selatan.

\section{Metode Pelaksanaan}

Pada penelitian ini menggunakan prosedur analisis dari Soft System Methodologi (SSM), karena dapat berkonsentrasi melihat perspektif stakeholder yang terlibat dalam pembentukan Klinik Berhenti Merokok dengan mengembangkan aplikasi android "Diet Rokok" dalam memfasilitasi masyarakat sebagai pengguna (user). Selain itu, alat yang digunakan (CATWOE dan Rich Picture) mudah untuk digunakan dan dipahami, hal ini memungkinkan partisipasi lanjutan dari kelompok pengguna. Jadi manfaat utama dari SSM adalah membuat keinginan untuk pindah dari masalah tidak terstrukturmenjadi masalah terstruktursesuai dengan perubahan yang diinginkan (Sumadyo, 2016). Dengan menggunakan analisis CATWOE, membantu mengurangi situasi yang kompleks menjadi beberapa kunci yang relevan.

Dalam pemecahan masalah pencegahan perilaku merokok di masyarakat, erat kaitannya dengan masalah perilaku manusia, yang sudah menjadi kebiasaan dan budaya di masyarakat, sehingga kompleksitas masalah nya harus diselesaikan mealui berpikir strategis dan solutif, sehingga penggunaan analisis Soft System Methodologi (SSM) sangat tepat dalam menyelesaikan maslah tersebut. Dalam studi kasus ini, metodologi SSM secara sistemik digunakan sebagai pedoman untuk diskusi tentang situasi-masalah kompleksitas perilaku manusia, seperti yang dinyatakan oleh Checkland (2010). SSM berisi penjelasan yang logis untuk aplikasi ilmiah yang dibagi menjadi 7 tahapan sebagai berikut (Checkland, 2010): 1) menemukan masalah, 2) mengekspresikan situasi masalah, 3) mendapatkan definisi hakiki dari sistem, 4) membuat model konseptual, 5) membandingkan model konseptual dengan situasi 
yang digambarkan pada dunia nyata atau tahap kedua, 6) perubahan yang desirable - feasible dan 7) saran perbaikan.

Pada tahap pertama proses menemukan masalah sama hal nya dengan mengkaji masalah yang tidak terstruktur melalui studi analisis situasi. Kkemudian pada tahap mengekspresikan situasi masalah dilakukan analisis data dan observasi serta interview pakar yang terlibat. Sehingga dapat terbentuk Rich-picture, dimana melakukan makna nilai dari rich picture.

Pada tahap ketiga mendapatkan definisi hakiki dari system dilakukan identifikasi CATWOE kemudian dikembangkan menjadi model konseptual, yang meliputi sebagai berikut: 1) Costumers adalah mereka yang mendapat keuntungan atau korban dari Transformasi; 2) Actors adalah mereka yang harus melakukan transformasi; 3) Transformations Process adalah perubahan dari input ke output; 4) Weltaanschauung (Jerman) worldview, yang menjadikan Transformasi bermakna dalam konteks. Owners, mereka yang dapat menghentikan Transformasi; 5) Environmental Constraint, elemen luar dari sistem yang dibutuhkan.

Tahap keempat embuat model konseptual dilakukan dengan embangun model konseptual berdasarkan analisa pada tahap ketiga, dimana harus dapat menyajikan info representasi grafis dari perspektif pada RD. Tahap membandingkan model konseptual dengan situasi yang digambarkan pada dunia nyata / tahap kedua. Melihat perbandingan kesesuaian dengan realitasnya. Jika realitasnya bisa diimplementasikan maka proses selanjutnya melakukan pengembangan intervensi dengan melakukan perubahan yang diinginkan.

Tahap keenam perubahan yang desirable - feasible, pada tahap ini, ditentukan perubahan yang diinginkan dan layak dilakukan secara sistematis. Dan pada tahap ketujuh saran perbaikan, setelah itu model strategi diimplementasikan maka dapat diajukan saran agar dapat melaksankan pengembangan program Klinik Berhenti Merokok

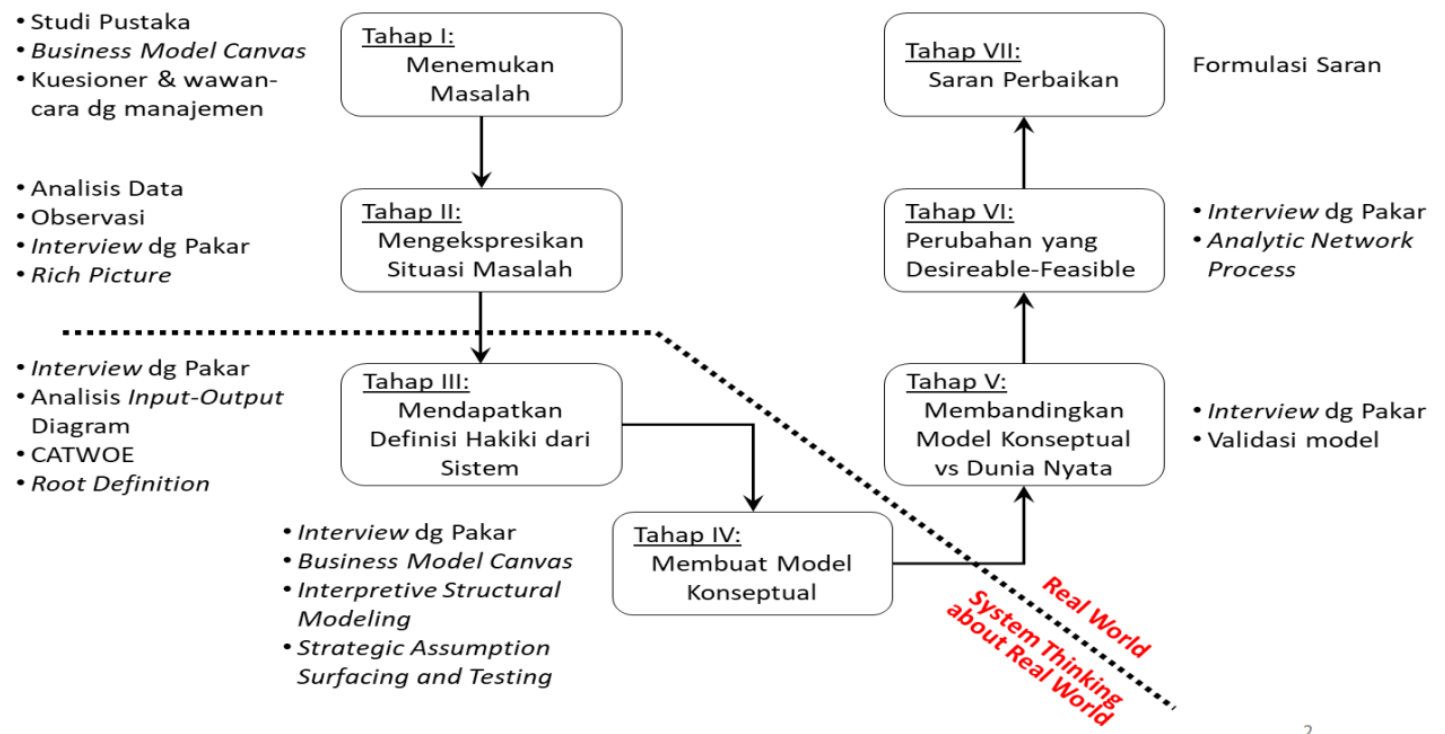


Pada proses pengumpulan data, dilakukan dengan menggunakan survey cepat pada masyarakat untuk melihat analisis situasi. Sedangkan untuk menentukan akar masalah menggunakan metode pohon masalah dengan Teknik FGD lebih sering digunakan dalam penelitian kualitatif oleh para pembuat keputusan (Kalsum et al., 2020). Pelaksanaan FGD dihadiri oleh berbagai elemen masyarakat, seperti ketua RW, kepala desa, dan kader Kesehatan di masyarakatdan pihak pelaksana teknis dari Puskesmas Kampung Sawah serta Dinas Kesehatan Tangerang Selatan, untuk berdiskusi secara terstruktur mengenai Analisa situasi hingga alternatif solusi dengan kesepakatan bersama. Selain menggunakan Teknik FGD peneliti juga menggunakan metode observasi partisipatif untuk mendukung gambaran situasi di masyarakat (William, 2012). Dari hasil observasi kemudian dicatat hasil pengamatan untuk mengetahui apa yang sebenarnya terjadi (Checkland, 2010).

\section{Hasil dan Pembahasan}

Berdasarkan hasil analisis Pengembangan Klinik Berhenti Merokok menggunakan Soft System Methodologi (SSM) yaitu sebagai berikut:

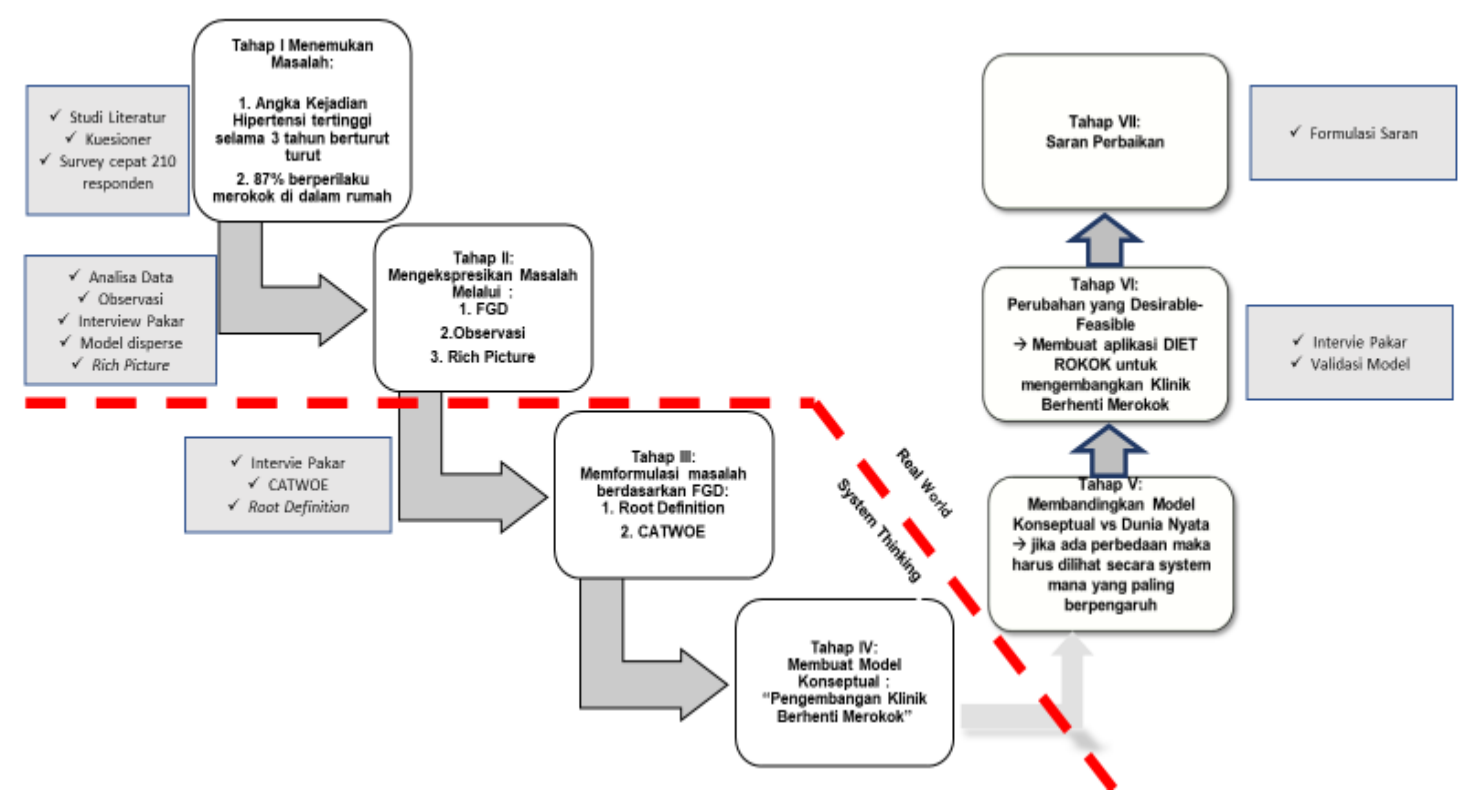

Sumber: (Checkland, 2010)

Gambar 2. Soft System Methodologi (SSM) Pengembangan Klinik Berhenti Merokok

\subsection{Menemukan Masalah}

Pada tahap pertama proses menemukan masalah melalui studi analisis situasi. Hasil dari studi analisis situasi di Wilayah Kampung Sawah, Tangerang Selatan diperoleh melalui survey cepat kepada 210 responden. Dari hasil analisis situasi berdasarkan survey cepat kepada 210 responden diketahui presentase perilaku merokok berdasarkan RW di wilayah Kampung Sawah Kota Tangerang Selatan, yaitu sebagai berikut. 


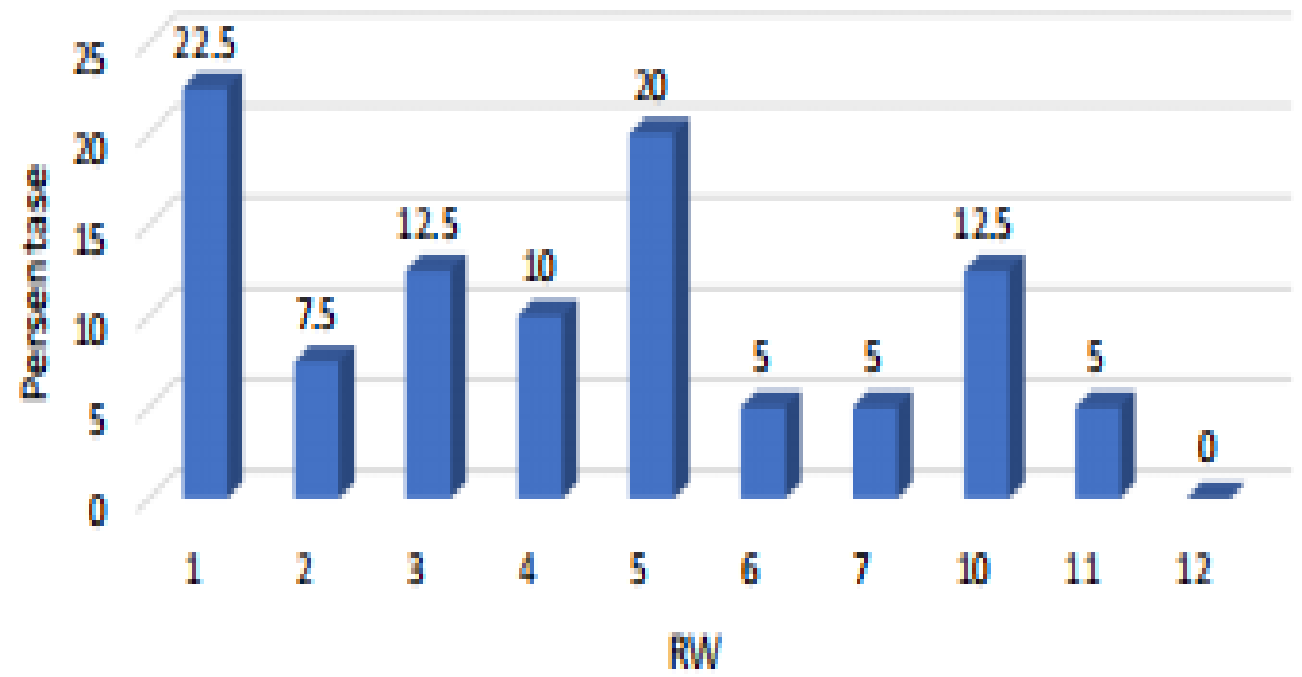

Sumber: Hasil Pelaksanaan (2020)

Gambar 3. Presentase Perilaku Merokok Berdasarkan RW di Wilayah Kampung Sawah Kota Tangerang Selatan

Sedangkan berdasarkan FGD yang dilakukan bersama ketua RW, kepala desa, dan kader Kesehatan di masyarakatdan pihak pelaksana teknis dari Puskesmas Kampung Sawah serta Dinas Kesehatan Tangerang Selatan, diketahui akar masalah Kesehatan yang ada di pengaruh orang tua, teman, iklim, demografis, psikologis, kepribadian, sosial politik, lingkungan sosial, sosial kultural, biologis dan pengetahuan masyarakat. Hal tersebut disajikan pada gambar pohon masalah berikut.

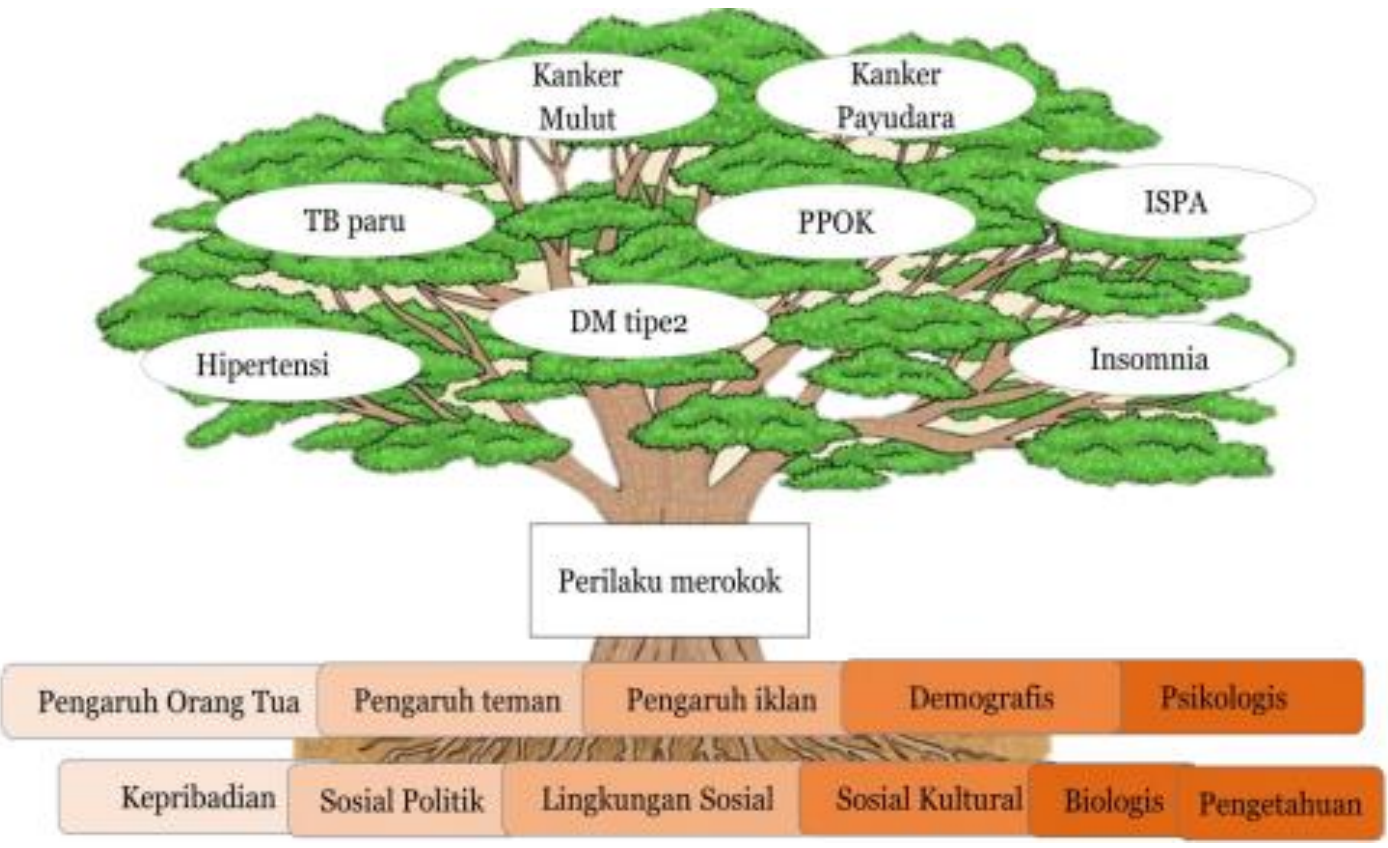

Sumber: Hasil Pelaksanaan (2020)

Gambar 4. Penentuan Akar Masalah Perilaku Merkok berdasarkan Pohon Masalah 


\subsection{Mengekspresikan Situasi Masalah}

Setelah analisa situasi diketahui, maka dilakukan analisis data dan observasi serta interview pakar yang terlibat. Sehingga dapat terbentuk Rich-picture, dimana melakukan makna nilai dari rich picture. Gambar 5 menunjukkan gambaran mengenai rich picture model pengembangan klinik berhenti merokok sebagai upaya penurunan perilkau merokok di Tangerang Selatan

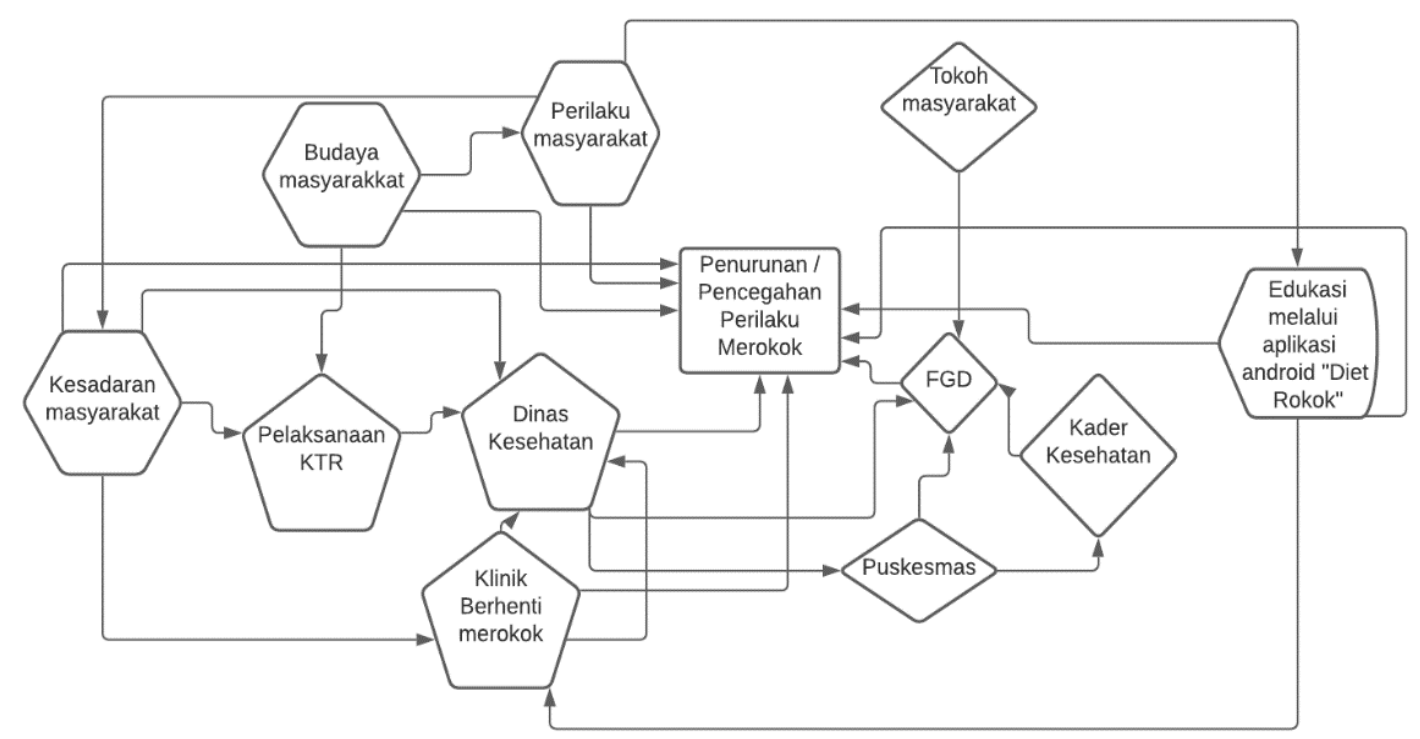

Sumber: Hasil Pelaksanaan (2020)

Gambar 5. Rich Picture Model Pengembangan Klinik Berhenti Merokok

Makna Rich Picture pada model pengembangan klinik berhenti merokok sebagai upaya penurunan perilkau merokok di Tangerang Selatan merupakan proses membuat root definitions (RD) yaitu mendeskripsikan proses transformasi untuk mencapai tujuan. Gambar 6 menunjukkan root definition model pengembangan klinik berhenti merokok sebagai upaya penurunan perilkau merokok di Tangerang Selatan

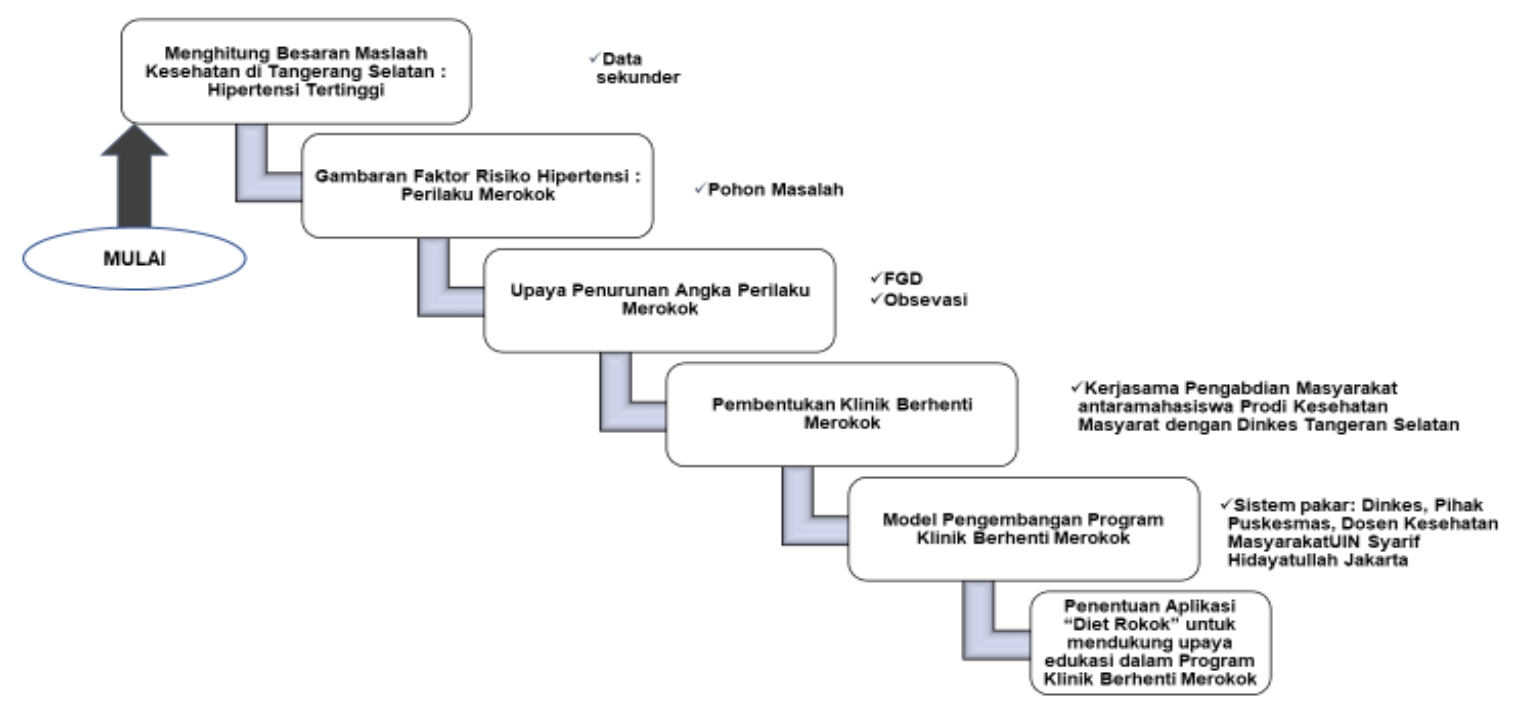

Sumber: Hasil Pelaksanaan (2020)

Gambar 6. Root Definition Model Pengembangan Klinik Berhenti Merokok 


\subsection{Memdapatkan Definisi Hakiki Dari Sistem}

Analisis terhadap root definitions dilakukan dengan menggunakan identifikasi CATWOE kemudian dikembangkan menjadi model konseptual pada system Pengembangan Klinik Berhenti Merokok di Tangerang Selatan, yang meliputi sebagai berikut:

Tabel 1. Analisis CATWOE

\begin{tabular}{ll}
\hline \multicolumn{1}{c}{ CATWOE } & \multicolumn{1}{c}{ Definisi } \\
\hline Customers & Masyarakat dan perusahaan rokok \\
\hline Actors & Masyarakat, Pemerintah, Dinas Kesehatan, Puskesmas \\
\hline Transformation & Pengembangan Klinik Berhenti Merokokk melalui Aplikasi \\
& Android "Diet Rokok \\
\hline World view & Perubahan perilaku masyarakat untuk mengurangi konsumsi \\
& rokok dan pelaksanaan UU Kawsan Tanpa Rokok \\
\hline Owners & uskesmas dan Dias Kesehatan Tangerang Selatan \\
\hline Environmental & Perlu adanya inovasi dalam pengembangan Klinik Berhenti \\
Constraint & Merokok dan Ruangan Khusus Klinik Berhenti Merokok di \\
& Puskesmas
\end{tabular}

Sumber: Hasil Pelaksanaan (2020)

\subsection{Membuat Model Konseptual}

Membuat model konseptual berdasarkan Analisa pada tahap ketiga, dimana harus dapat menyajikan info representasi grafis dari perspektif pada RD. Membandingkan model konseptual dengan situasi dunia nyata, diperoleh model konseptual Pengembangan Klinik Berhenti Merokok sebagai Upaya Penurunan Perilkau Merokok di Tangerang Selatan Sebagai berikut:

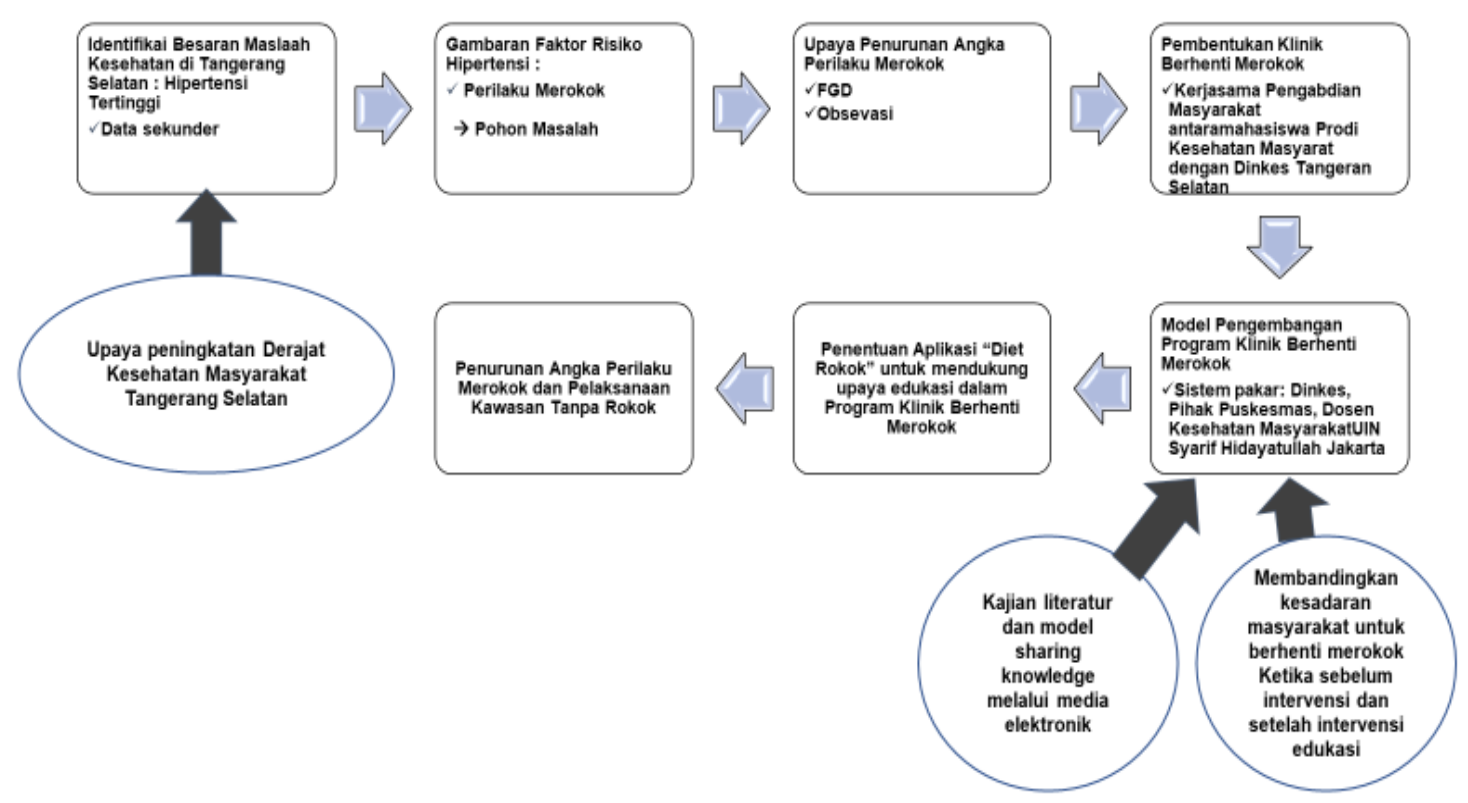

Sumber: Hasil Pelaksanaan (2020)

Gambar 7. Model Konseptual Model Pengembangan Klinik Berhenti Merokok 


\subsection{Membandingkan Model Konseptual Dengan Situasi Digambarkan Pada Dunia Nyata / Tahap Kedua}

Perbandingan model konseptual pengembangan klinik berhenti merokok sebagai upaya penurunan perilkau merokok di Tangerang Selatan dengan situasi yang digambarkan melalui Analisa Pohon Maslah, dengan mempertimbangkan pada akar masalah dan alternatif solusi yang dijabarkan pada table sebagai berikut:

Tabel 2. Perbandingan Akar Masalah dan Alternatif Masalah

\begin{tabular}{|c|c|c|}
\hline Akar Maslaah & Alternatif Solusi & Sasaran \\
\hline $\begin{array}{l}\text { Mereka yang memeiliki } \\
\text { pengetahuan yang rendah } \\
\text { tentang rokok berpeluang } 7 \\
\text { kali untuk berprilaku merokok } \\
\text { dibandingkan degan mereka } \\
\text { yang berpengetahuan tinggi }\end{array}$ & $\begin{array}{l}\text { Penyuluhan berisi tentang bahaya } \\
\text { merokok dampak dari berbagai } \\
\text { Kesehatan akibat rokok, bertujuan } \\
\text { untuk meningkatkan pengetahuan, } \\
\text { sikap dan memotivasi perokok untuk } \\
\text { berhenti merokok }\end{array}$ & (Sasaran: Masyarakat) \\
\hline $\begin{array}{l}\text { Dari factor kepribadian } \\
\text { perokok mereka yang tau dan } \\
\text { sadar akan bahaya rokok } \\
\text { serta mereka yang ingin } \\
\text { berhenti merokok karena ingin } \\
\text { melepaskan dirinya dari rokok }\end{array}$ & $\begin{array}{l}\text { Program diet rokok. kegiatan ini } \\
\text { memberikan motivasi dan } \\
\text { pengetahuan tentang rokok kepada } \\
\text { sasaran. }\end{array}$ & $\begin{array}{l}\text { (Sasaran: Perokok yang } \\
\text { ingin berhenti merokok) }\end{array}$ \\
\hline $\begin{array}{l}\text { Sasaran pada psikologis } \\
\text { perokok untuk memberikan } \\
\text { kesadara pada dirinya terkait } \\
\text { bahaya merokok bagi dirinya } \\
\text { dan yang lainnya. }\end{array}$ & $\begin{array}{l}\text { Menempel stiker. Kegiatan ini } \\
\text { dilakukan untuk memberi kesadaran } \\
\text { bagi si perokok, }\end{array}$ & (Sasaran: Masyarakat) \\
\hline $\begin{array}{l}\text { Pada kegiatan ini membentuk } \\
\text { lingkungan sosial yang dapat } \\
\text { menyediakan para peroko } \\
\text { sarana atau tempat berkumpul } \\
\text { para perokok untuk merokok, } \\
\text { kegiatan ini agar tidak } \\
\text { merugikan keluarga yang } \\
\text { lainnya atasi perokok pasif }\end{array}$ & $\begin{array}{l}\text { Pojok rokok. Kegiatan yang } \\
\text { bekerjasama dengan pihak } \\
\text { kelurahan untuk menyediakan } \\
\text { sarana pojok rokok }\end{array}$ & (Sasaran: Masyarakat) \\
\hline
\end{tabular}

Pada upaya meningkatkan angka pencegahan atau berhenti merokok, metode atau terapi yang akan dipilih dipengaruhi oleh informasi yang diperolehnya. Metode berarti implementasi atau penerapan dari apa yang sudah direncakan(Alamsyah, 2017). Pemilihan metode yang tepat akan menentukan tingkat keberhasilan kegiatan. Metode yang dipilih oleh ketiga informan adalah metode pengobatan (therapy), perubahan perilaku (changing behaviour), dan dorongan positif (positive encouragement). Semua metode yang dipakai informan didasarkan pada niat yang kuat (strong will) (Fawzani \& Triratnawati, 2005). 
Cara yang ditempuh untuk berhenti merokok antara lain dengan metode pengobatan yaitu mencari obat yang bisa menyembuhkan kecanduan terhadap rokok. Metode lain yaitu perubahan perilaku yaitu seseorang berubah tanpa bantuan obat melainkan hanya berhenti begitu saja melalui perubahan perilaku dengan menjauhi dan menghindari rokok. Metode ketiga yaitu dorongan positif artinya memasukkan pikiran dan perilaku positif yang diinginkan. Ketiga bentuk terapi yang dipilih untuk berhenti merokok dalam pelayanan kesehatan menurut Kleinman termasuk dalam sektor populer, karena informasi pelayanan kesehatan yang dipilih hanya didasarkan atas nasihat teman, keluarga, atau orang awam dan bukan dari kelompok medis (Fawzani \& Triratnawati, 2005).

\subsection{Perubahan Desirable - Feasible}

Pada tahap ini, ditentukan perubahan yang diinginkan dan layak dilakukan secara sistematis. Perubahan yang terjadi dapat berupa perubahan hal struktur, prosedur atau sikap orang-orang. Pada Model Pengembangan Klinik Berhenti Merokok di Tangerang Selatan menghasilkan strategi intervensi untuk memperbaiki situasi.

Adapun kegiatan dari klinik berhenti merokok ini adalah konseling dilihat indikator penilaian capaiannya kegiatan intervensi yang dilakukan adalah input, proses dan output.

Input, terdiri dari 1) Man, tersedianya konselor berhenti merokok. 2) Money, tersedianya dana oleh puskesmas dan pemerintah daerah. 3) Materials, tersedianya petunjuk teknis, brosur dan perangkat Klinik Berhenti Merokok, tersedianya media berupa leaflet dan poster dan tersedianya media $X$-banner dan banner kegiatan. 4) Method konseling sesuai dengan petunjuk teknis. 5) Machine, tersedianya ruangan Klinik Berhenti Merokok.

Proses, terdiri dari 1) mendapatkan izin dari Kepala Puskesmas untuk Pengadaan Klinik Berhenti Merokok di Puskesmas Kampung Sawah, 2) adanya komitmen bersama Klinik Berhenti Merokok dengan UIN Syarif Hidayatullah Jakarta, Puskesmas Kampung Sawah, Kecamatan Ciputat, Kelurahan Sawah serta warga Kelurahan Sawah, 3) pembuatan Petunjuk teknis, SOP, kerangka acuan, media sosialisasi untuk berhenti merokok, 4) terlaksananya launching Klinik Berhenti Merokok, 5) acara launching dihadiri oleh para tamu undangan yaitu pihak kecamatan, kelurahan, puskesmas, kader serta dosen Prodi Kesehatan Masyarakat UIN Syarif Hidayatullah Jakarta.

Output ditunjukkan dengan 1) terlaksananya konseling sebanyak 2 kali selama masa intervensi, 2) target klien yang berkunjung ke klinik berhenti merokok sebanyak 5 orang, 3) terlaksananya komitmen bersama dalam rangka mendukung Klinik Berhenti Merokok, 4) tersedianya petunjuk teknis konseling berhenti merokok bersumber dari Kemenkes RI, SOP, dan kerangka acuan, 5) tersedianya media poster dan leaflet untuk berhenti merokok.

Gambar 8 menunjukkan dokumentasi dari rangkaian kegiatan pelaksanaan acara launching Klinik Berhenti Merokok. 

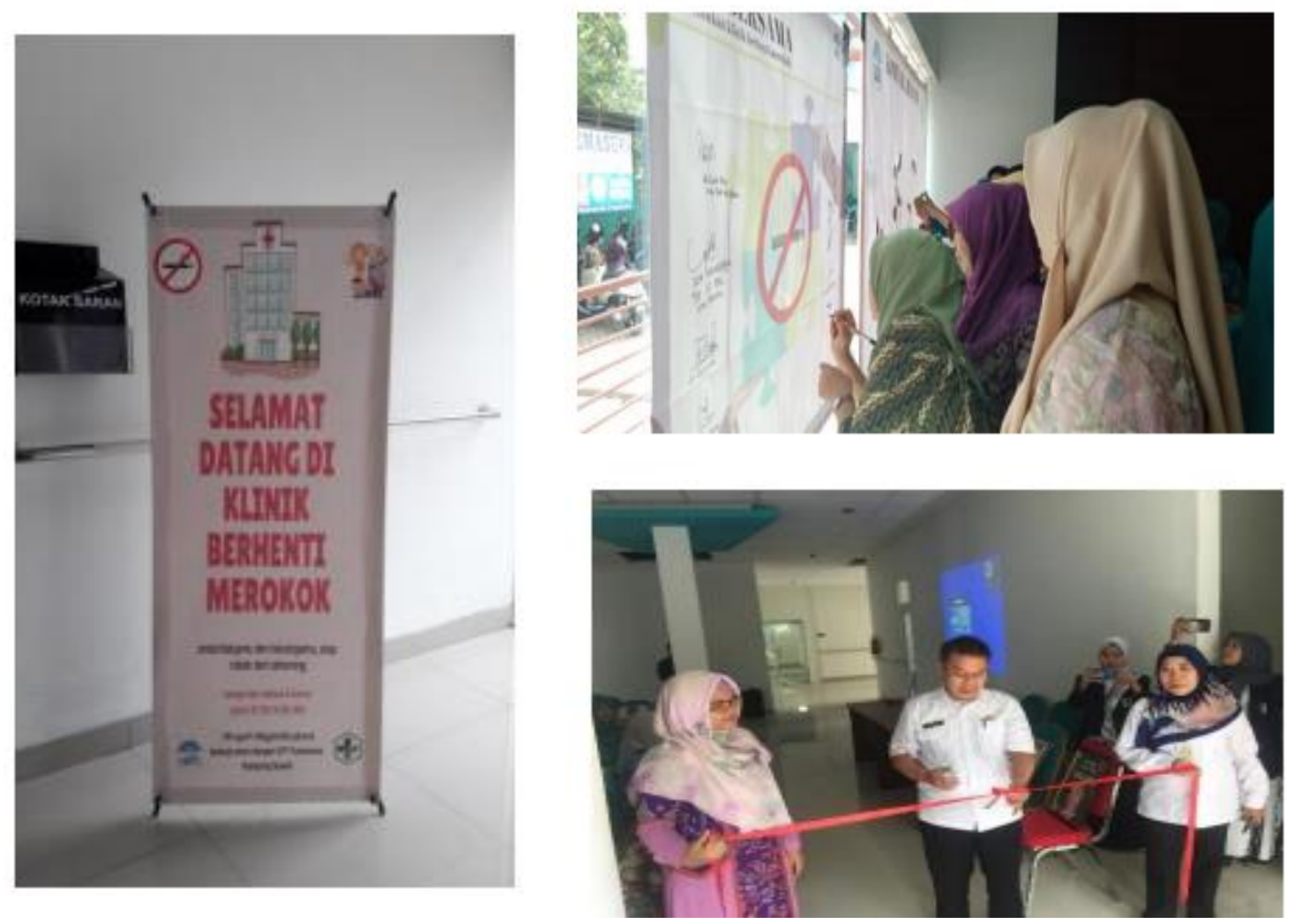

Sumber: Hasil Pelaksanaan (2020)

Gambar 8. Acara Launching Klinik Berhenti Merokok

Gambar 9 menunjukkan bebrapa media intervensi yang digunakan pada Klinik Berhenti Merokok di Tangerang Selatan.
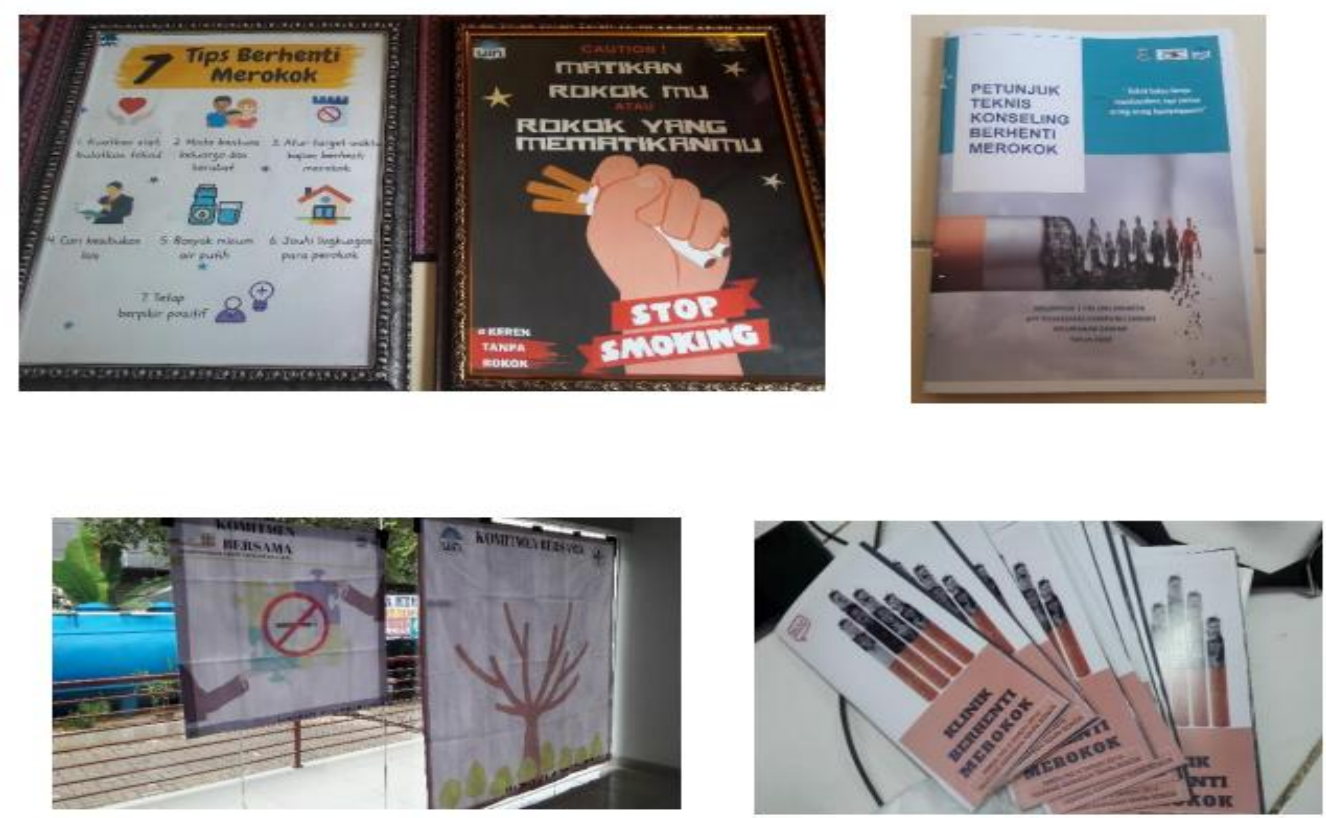

Sumber: Hasil Pelaksanaan (2020)

Gambar 9. Media Intervensi pada Klinik Berhenti Merokok di Tangerang Selatan 
Model intervensi klinik berhenti merokok dalam kegiatan intervensi Klinik Berhenti Merokok merupakan pemberdayaan Model B (Social Planning). Model B (Social Planning) adalah kegiatan yang mementingkan tercapainya tujuan, metode pemecahan masalah yang bersifat rasional, empiris (Mufiz, 2016). Proses menekankan pada aspek teknis dalam penyelesaian masalah dengan melalui perencanaan yang baik dan rasional, sedangkan partisipasi masyarakat sifatnya bervariasi tergantung dari permasalahan yang dihadap i. Pada kegiatan Klinik Berhenti Merokok, tim pengabdian masyarakat berperan dalam mengadvokasi, perizinan, mendiskusikan konselor, membuat petunjuk teknis dan dokumen terkait Klinik Berhenti Merokok, mendiskusikan penentuan ruangan klinik, membuat media, launching Klinik serta pelaksanaan konseling.

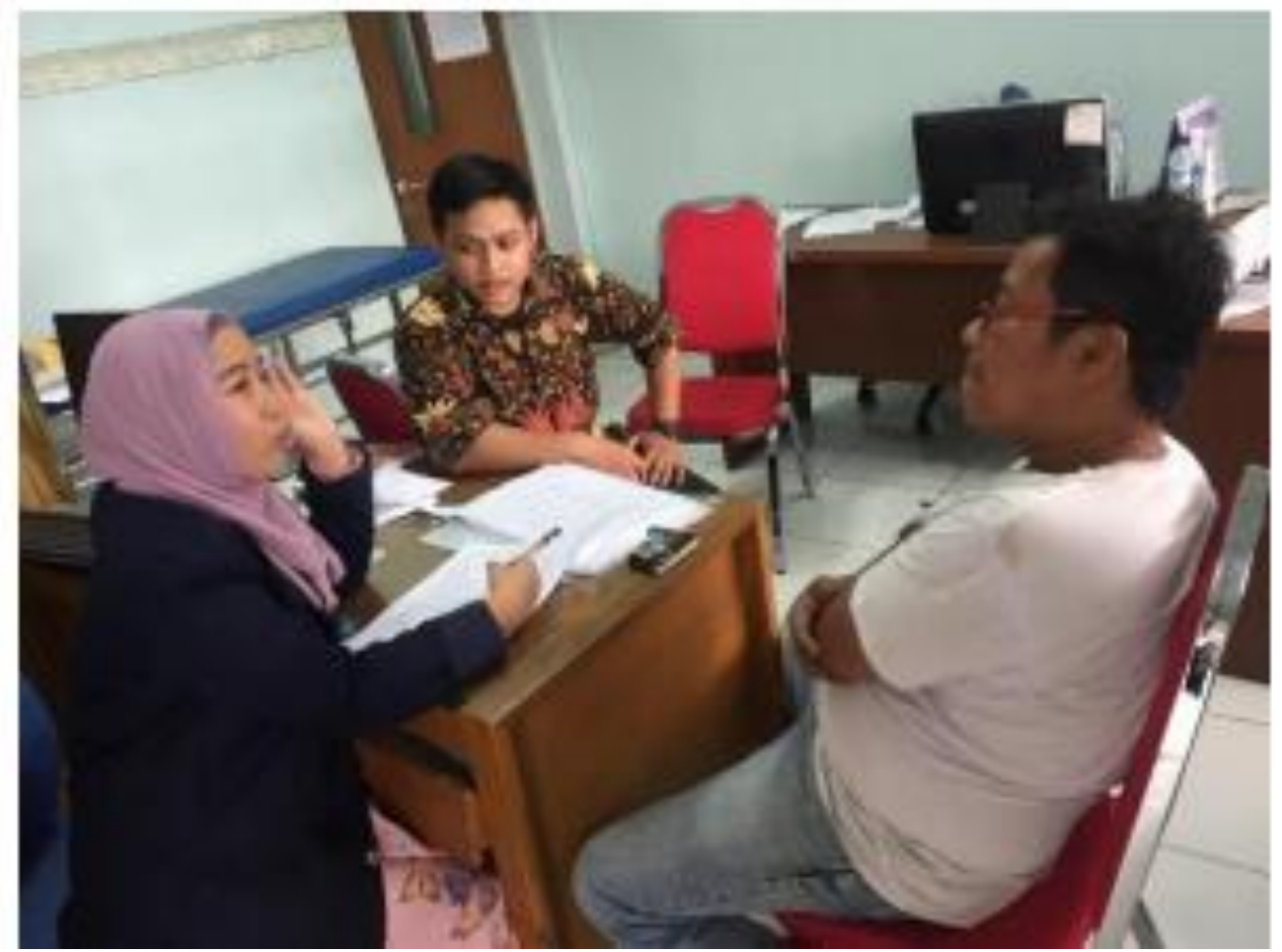

Sumber: Hasil Pelaksanaan (2020)

Gambar 10. Kegiatan Konseling di Klinik Berhenti Merokok

\subsection{Saran Perbaikan}

Setelah strategi Pengembangan Klinik Berhenti Merokok di Tangerang Selatan diimplementasikan maka berdasarkan monitoring dan evaluasi ada beberapa hal yang dapat dilaksanakan untuk mengembangkan Klinik Berhenti Merokok di Tangerang Selatan, sebagai berikut: 1) Melaksankan pengembangan program Klinik Berhenti Merokok melalui aplikasi aplikasi android. Hal ini sesuai dengan penelitian Businelle (2016) diketahui bahwa penggunaan aplikasi smartphone dapat membantu seseorang dalam program berhenti merokok. 2) Melakukan kegiatan edukasi secara rutin oleh kader Kesehatan, agar program Klinik Berhenti Merokok di yang berada di Puskesmas dapat dimanfaatkan secara maksimal. 3) Masyarakat diharapkan mensosialisasikan Klinik Berhenti Merokok di Puskesmas. 


\section{Kesimpulan}

Berdasarkan Analisa Soft System Methodologi (SSM) dapat membantu dalam berpikir system untuk menyelesaikan permasalahan perubahan perilaku masyarakat yang komplesitasnya tinggi, namun dapat diselesaikan melalui alternatif solusi yang terstruktur dengan baik. Berdasarkan analisa situasi yaitu prevalensi perilaku merokok di Provinsi Banten melebihi angka rata-rata Nasional (29,3\%), yaitu sebesar 31,3\%. Sehingga solusi alternatif terbaik dapat dilakukan melalui Pembentukan Klinik Berhenti Merokok, yang merupakan implementasi dari upaya penurunan angka perilaku merokok dalam kegiatan Pengabdian Masyarakat yang dilakukan oleh Program Studi Kesehatan Masyarakat UIN Syarif Hidayatullah Jakarta bekerja sama dengan Dinas Kseehatan Tangerang Selatan dan Puskesmas Kampung Sawah. Pengembangan program Klinik Berhenti Merokok dapat dilakukan dengan cara kegiatan edukasi secara elektronik melalui aplikasi android yang dirancang sebagai alternatif pengembangan media untuk memberikan edukasi secara online.

\section{Ucapan Terima Kasih}

Terima kasih kepada seluruh elemen yang turut membantu dalam proses pengabdian masyarakat yang dilaksanakan oleh Prodi Kesehatan Masyarakat Fakultas IImu Kesehatan UIN Syarif Hidayatullah Jakarta yang bekerjasama dengan Dinas Kesehatan Tangerang Selatan, Puskesmas Kampung Sawah, Kelurahan Kampung Sawah, Kader Kesehatan dan Tim Pelaksana Pengabdian Masyarakat Prodi Kseeahatan Msyarakat yang meliputi : Siti Devina, Dwi Fakhrulia, Feny Oktovianty, Shanaz Elvira, Risma Destiana, Fanny Eldiana, Nisrina Rahmatua, dan Fadzila Nur Utami yang telah berperan dalam kegiatan teknis dan memberikan waktu serta tenaga dalam pelaksanaan Pengabdian Masyarakat dalam Pengembangan Klinik Berhenti Merokok di Tangerang Selatan.

\section{Daftar Pustaka}

Alamsyah, A. (2017). Determinan Perilaku Merokok Pada Remaja. Jurnal Endurance, 2(1), 25. https://doi.org/10.22216/jen.v2i1.1372

Checkland, P. (2010). Researching real-life: reflections on 30 years of action research. Systems Research and Behavioral Science, 27, 129+.

Davis, A., Ngo, H., \& Coleman, M. (2019). An evaluation of a pilot specialist smoking cessation clinic in a mental health setting. Australasian Psychiatry: Bulletin of Royal Australian and New Zealand College of Psychiatrists, 27(3), 275-278. https://doi.org/10.1177/1039856218816372

Fawzani, N., \& Triratnawati, A. (2005). Terapi Berhenti Merokok. British Medical Journal, 9(1), $15-22$.

Geneva: World heald Organization. (2018). Who global report on trends in prevalence of tobacco smoking 2000-2025, second edition.

Kalsum, U., Yamin, M. N., \& Rasyid, E. (2020). Strategi dan Model Komunikasi Konseling Klinik 
Berhenti Merokok. JHeS (Journal of Health Studies), 4(2), 1-11. https://doi.org/10.31101/jhes.1177

Kementrian Kesehatan RI. (2018). Situasi Umum Konsumsi Tembakau di Indonesia. Pusat Data Dan Informasi Kementrian Kesehatan RI, ISSN 2442-7659, 06-07.

Mufiz, A. (2016). Pengantar IImu Administrasi Negara. Jakarta: Graha IImu, 2(11), 247-248.

Perdana, E. M., Manongga, D., \& Iriani, A. (2019). Model Konseptual bagi Pengembangan Knowledge Management di SMA Menggunakan Soft System Methodology. Jurnal $\begin{array}{lllll}\text { Teknologi Informasi Dan Ilmu Komputer, } & \text { 6(2), }\end{array}$ https://doi.org/10.25126/jtiik.201962932

Sumadyo, M. (2016). Penggunaan Teknik Analisis Dalam Pengembangan Sistem Informasi Menggunakan Soft System Methodology ( Ssm ) Pendahuluan Sistem kerja adalah suatu sistem yang produk bagi pelanggan eksternal maupun internal . Organisasi dapat dipandang sebagai kumpulan yang. 4(1), 36-48.

Tseng, Y.-F., Wang, K.-L., Lin, C.-Y., Lin, Y.-T., Pan, H.-C., \& Chang, C.-J. (2018). Predictors of smoking cessation in Taiwan: using the theory of planned behavior. Psychology, Health \& Medicine, 23(3), 270-276. https://doi.org/10.1080/13548506.2017.1378820

WHO. (2020). Raise Tobacco Taxes and Prices for a Healthy and Prosperous Indonesia. 1-19. https://www.who.int/docs/default-source/searo/indonesia/indonesia-tobacco-tax-paper2020.pdf?sfvrsn=67c3d89a_2

William, B. (2012). Evaluating the Efficacy of Focus Group Discussion (FGD) in Qualitative Social Research. International Journal of Business and Social Science, 3(7), 54-57. http://www.ijbssnet.com/journals/Vol_3_No_7_April_2012/6.pdf 